\title{
ANALISIS SITUASI PENGELUARAN DAN KONSUMSI RUMAH TANGGA TERHADAP KOMODITAS IKAN DI INDONESIA
}

\author{
Siti Hajar Suryawati, Subhechanis Saptanto dan Sonny Koeshendrajana")
}

\begin{abstract}
ABSTRAK
Riset bertujuan untuk mengkaji situasi pengeluaran dan konsumsi rumah tangga untuk komoditas ikan di Indonesia telah dilakukan pada tahun 2004. Metoda eksploratif-analitik digunakan dalam kajian tersebut. Analisis deskriptif statistik digunakan untuk eksplorasi data SUSENAS tahun 1996, 1999 dan 2002. Hasil analisis menunjukkan bahwa pengeluaran rumah tangga untuk ikan meningkat dengan makin tingginya pengeluaran rumah tangga. Akan tetapi tidak demikian dengan tingkat konsumsi ikannya baik di daerah perkotaan maupun pedesaan.
\end{abstract}

\begin{abstract}
Analysis of households' expenditure and consumption of fish commodity in Indonesia. By: Siti Hajar Suryawati, Subhechanis Saptanto and Sonny Koeshendrajana
\end{abstract}

\begin{abstract}
Research aimed at assessing households' expenditure and consumption of fish commodity in Indonesia was conducted in 2004. An exploratory and analytical method was used in this study. A descriptive statistical method was used to explore the Nature Social and Economic Survey of the year 1996, 1999 and 2002. Results indicate that household expenditure for fish consumption increases as the household total expenditure increases. However, fish consumption decreased in the urban and rural area.
\end{abstract}

KEYWORDS: $\quad$ household expenditure, fish consumption, Indonesia

\section{PENDAHULUAN}

Ikan merupakan salah satu sumber daya perairan utama dan sumber protein, lemak, vitamin serta mineral yang sangat baik dan prospektif. Keunggulan utama protein ikan dibandingkan dengan produk lainnya adalah kelengkapan komposisi asam amino dan kemudahannya untuk dicerna. Ikan dikenal sebagai penghasil dan kaya akan lemak omega-3 dan omega-6 yang sangat esensial dalam pertumbuhan fungsi sel. Oleh karena itu, ikan merupakan pilihan tepat bagi pemenuhan gizi masyarakat (Anon., 2004 a).

Tingkat konsumsi ikan masyarakat Indonesia masih rendah, walaupun umumnya mereka bermukim di kawasan pesisir pantai. Terbukti hingga Desember 2003 tingkat konsumsi ikan per orang di Indonesia rata-rata $24,67 \mathrm{~kg}$ per tahun. Volume ini tergolong rendah dibanding konsumsi ikan di Korea Selatan dan Jepang yang rata-rata di atas $100 \mathrm{~kg} /$ orang/tahun atau Thailand yang mencapai $35 \mathrm{~kg} / \mathrm{orang} / \mathrm{tahun}$ (Anon., 2004 b).

Konsumsi pangan sangat penting artinya bagi kesehatan tubuh manusia. Hal ini karena untuk menjaga kesehatan tubuh kita bukan saja perlu mengkonsumsi pangan yang berkualitas (bergizi) tetapi juga mencapai jumlah kuantitas (status gizi) tertentu. Widyakarya Nasional Pangan dan Gizi V (WKNPG, 1994) merekomendasikan bahwa angka kecukupan protein bagi penduduk Indonesia adalah sebesar $48 \mathrm{gram} / \mathrm{kapita} / \mathrm{hari}$ di tingkat konsumsi atau sekitar $55 \mathrm{gram} / k a p i t a / h a r i ~ d i ~ t i n g k a t ~ k e t e r s e d i a a n$. Sekitar 30\% dari angka kecukupan di tingkat konsumsi tersebut (setara $15 \mathrm{gram} / \mathrm{kapita/hari)}$ seyogyanya dipenuhi dari pangan hewani. Anjuran konsumsi protein hewani tersebut diharapkan dapat dipenuhi dengan mengkonsumsi 9 gram produk ternak dan 6 gram produk ikan.

Tahun-tahun belakangan ini konsumsi ikan masyarakat Indonesia cenderung meningkat karena kesadaran untuk memproduksi dan mengkonsumsi ikan makin kuat. Perkembangan konsumsi ikan per kapita nasional pada periode tahun 2000-2004 mengalami peningkatan sebesar $1,68 \%$, yakni dari $21,57 \mathrm{~kg} / \mathrm{kap} / \mathrm{thn}$ pada tahun 2000 menjadi $23,18 \mathrm{~kg} /$ kap/thn pada tahun 2004 (DKP, 2004). Namun peningkatan konsumsi ini tidaklah secepat laju peningkatan konsumsi pangan hewani selain ikan terutama daging ayam dan telur. Padahal Indonesia merupakan negara maritim yang kaya dengan berbagai jenis ikan yang dapat dimanfaatkan sebagai pangan sumber protein hewani.

Bagi penentu kebijakan di sektor kelautan dan perikanan, permasalahan yang seringkali dijumpai

\footnotetext{
") Peneliti pada Balai Besar Riset Sosial Ekonomi Kelautan dan Perikanan
} 
adalah sulitnya mendapatkan data dan informasi yang dapat dijadikan acuan berkaitan dengan ketersediaan produk perikanan yang sesuai dengan kebutuhan konsumen. Pada pasar domestik, data dan informasi tersebut dapat didekati dengan situasi dinamika pengeluaran dan konsumsi rumah tangga terhadap komoditas perikanan. Oleh karena itu tulisan ini bertujuan untuk mengkaji situasi pengeluaran dan konsumsi ikan di Indonesia, termasuk didalamnya adalah tingkat konsumsi dan tingkat partisipasinya.

\section{METODE}

Metode eksploratif analitik digunakan dalam studi ini. Data utama yang digunakan adalah data pengeluaran untuk Konsumsi Penduduk Indonesia hasil Survey Sosial Ekonomi Nasional (SUSENAS) tahun 1996, 1999 dan 2002. Deskripsi pengambilan contoh yang dilakukan pada Susenas adalah sebagai berikut: kerangka sampel yang digunakan terdiri dari 3 jenis yaitu kerangka sampel untuk pemilihan kecamatan (khusus untuk daerah pedesaan), kerangka sampel untuk pemilihan blok sensus, dan kerangka sampel untuk pemilihan rumah tangga.

Kerangka sampel untuk pemilihan sampel kecamatan di daerah pedesaan adalah daftar kecamatan dalam setiap kabupaten/kota yang telah diurutkan menurut letak geografis. Selanjutnya pemilihan blok sensus di daerah perkotaan adalah daftar blok sensus yang dibedakan menurut blok sensus yang terletak di perkotaan besar, perkotaan sedang, dan perkotaan kecil di setiap kabupaten/kota. Untuk daerah pedesaan, pemilihan blok sensus menggunakan daftar blok sensus yang terdapat dalam setiap kecamatan terpilih. Kerangka sampel untuk pemilihan rumah tangga adalah daftar rumah tangga yang terdapat dalam daftar yang disusun, misalnya untuk SUSENAS 2002 adalah daftar VSEN2002L Blok IV.

Untuk rancangan sampel adalah rancangan sampel bertahap dua untuk daerah perkotaan dan rancangan sampel bertahap tiga untuk daerah pedesaan. Untuk daerah perkotaan, tahap pertama, dari kerangka sampel blok sensus dipilih sejumlah blok sensus secara linier sistematik sampling. Kemudian tahap kedua, dari setiap blok sensus terpilih dipilih 16 rumah tangga juga secara linier sistematik sampling. Dan untuk daerah pedesaan dilakukan dalam tiga tahap, yaitu (a) dari kerangka sampel kecamatan dipilih sejumlah kecamatan secara probability proportional to size, dengan size banyaknya rumah tangga dalam kecamatan; (b) dari setiap kecamatan terpilih dipilin sejumlah blok sensus secara linier sistematik sampling dan (c) dari setiap blok sensus terpilih dipilih 16 rumah tangga juga secara linier sistematik sampling. Setiap rumah tangga terpilih diwawancarai secara langsung oleh petugas terlatih.

Metode eksplorasi yang dimaksudkan adalah melakukan eksplorasi data Susenas tahun 1996, 1999 dan 2002 dengan menggunakan deskripsi statistik ${ }^{1 !}$. Analisis dilakukan dengan melakukan pengelompokkan jenis-jenis ikan tercakup dalam Susenas dan mengaitkan dengan referensi-referensi yang tersedia. Preferensi konsumsi rumah tangga terhadap suatu barang atau komoditas dapat dicerminkan oleh tingkat "penggunaan atau pemilikan" barang atau komoditas tersebut oleh rumah tangga (Hardono \& Ariani, 1994). Berdasarkan pendapat tersebut, untuk mengetahui preferensi konsumsi ikan dapat didekati dengan melihat tingkat konsumsi dan partisipasi serta pengeluaran rumah tangga yang dialokasikan untuk belanja ikan.

Tingkat partisipasi konsumsi ikan diukur dengan cara menghitung persentase responden yang mengkonsumsi jenis ikan relatif terhadap total responden, dan tingkat konsumsi ikan dihitung berdasarkan satuan $\mathrm{kg} / \mathrm{kap} /$ tahun untuk masingmasing jenis ikan. Semakin tinggi tingkat konsumsi, tingkat partisipasi dan pengeluaran rumah tangga untuk belanja ikan dapat menunjukkan tingginya preferensi rumah tangga untuk mengkonsumsi ikan. Untuk memudahkan pemahaman, frekuensi konsumsi rumah tangga terhadap komoditas ikan dapat dinyatakan dengan situasi pengeluaran dan konsumsi ikan rumah tangga.

\section{HASIL DAN BAHASAN}

\section{Pengeluaran Rumah Tangga untuk Bahan Pangan dan Ikan}

Struktur pengeluaran menurut kelompok pangan atau komoditas memberikan informasi yang lebih komprehensif tentang deskripsi alokasi anggaran dan kesejahteraan masyarakat. Disamping merefleksikan tingkat kesejahteraan (dengan pertimbangan faktor tingkat pendapatan), pilihan pangan juga diwarnai oleh pertimbangan faktor sosial budaya seperti pendidikan, pemahaman tentang masalah gizi dan kesehatan, dan

\footnotetext{
1) Eksplorasi data Susenas 1996, 1999 dan 2002 dalam bentuk deskripsi statistik dilakukan dengan menggunakan Software SAS versi 8.2-e

2) Hal ini untuk penyederhanaan. Realita dinamika pengeluaran rumah tangga secara nominal sangat dipengaruhi oleh beberapa faktor, antara lain : inflasi, harga barang yang dikonsumsi dan ketersediaan barang di tempat lokal.
} 
adat istiadat setempat. Faktor sosial ini akan memberikan apresiasi yang berbeda terhadap kelompok komoditas tertentu seperti halnya juga ikan.

Pangsa pengeluaran rumah tangga untuk bahan pangan dan ikan dalam kurun waktu tahun 1996-2002 disajikan pada Tabel 1. Selama enam tahun dalam periode tersebut, rata-rata pengeluaran meningkat dari Rp 70.062,- per kapita per bulan menjadi Rp 206.336 per kapita per bulan atau meningkat sekitar $295 \%$. Pengeluaran tersebut meliputi pengeluaran untuk pangan dan bukan pangan. Seiring dengan peningkatan pengeluaran rumah tangga (sebagai proksi dari pendapatan) tampak bahwa proporsi pengeluaran rumah tangga untuk konsumsi pangan baik di perkotaan maupun pedesaan juga makin berkurang. Hal ini sesuai dengan hukum Engel yang dinyatakan oleh Nikijuluw (1997), menyebutkan bahwa apabila pendapatan meningkat maka proporsi alokasi pengeluaran bukan pangan meningkat, sedangkan pengeluaran untuk konsumsi pangan akan berkurang ${ }^{2}$.

Pada Tabel 1 dapat dilihat proporsi pengeluaran untuk konsumsi pangan di perkotaan berkurang $3,4 \%$ (dari $56,2 \%$ menjadi $52,8 \%$ ) sedangkan di pedesaan berkurang $3,6 \%$ (dari $70,2 \%$ menjadi $66,6 \%$ ). Meskipun ada kecenderungan adanya peningkatan bila dilihat dari tahun 1996, perlu kita pahami juga bahwa tahun 1999 itu merupakan tahun dimana krisis ekonomi melanda Indonesia dan tahun 2002 merupakan masa pemulihan dari krisis tersebut. Hal ini tentunya berdampak langsung terhadap pola

Tabel 1. Pangsa pengeluaran rumah tangga untuk konsumsi ikan (Rp/kap/b/n) menurut wilayah (desa-kota) di Indonesia, 1996-2002

Table 1. Household expenditure compartment for fish consumption (Rp/cap/month) by region (urban-rural) in Indonesia, 1996-2002

\begin{tabular}{|c|c|c|c|c|c|c|}
\hline \multirow{2}{*}{$\begin{array}{l}\text { Jenis pengeluaran/ } \\
\text { Type of expenditure }\end{array}$} & \multicolumn{2}{|l|}{1996} & \multicolumn{2}{|l|}{1999} & \multicolumn{2}{|l|}{2002} \\
\hline & $\begin{array}{c}\text { Rp/kap/binl } \\
\text { Rp/cap/month }\end{array}$ & $\%$ & $\begin{array}{c}\text { Rp/kap/b/n/ } \\
\text { Rp/cap/month }\end{array}$ & $\%$ & $\begin{array}{c}\text { Rp/kap/bln/ } \\
\text { Rp/cap/month }\end{array}$ & $\%$ \\
\hline KotalUrban: & & & & & & \\
\hline $\begin{array}{l}\text { 1. Ikan/ } \\
\text { Fish }\end{array}$ & 4.058 & $\begin{array}{c}4,0 \\
(8,4)\end{array}$ & 8.696 & $\begin{array}{c}4,8 \\
(8,6)\end{array}$ & 12.302 & $\begin{array}{c}4,5 \\
(8,5)\end{array}$ \\
\hline 2. Pangan/Food & 48.278 & 48,0 & 101.394 & 56,2 & 144.352 & 52,8 \\
\hline 3. Total/Total & 100.639 & 100,0 & 180.5 & 100,0 & 273.294 & 100,0 \\
\hline DesalRural: & & & & & & \\
\hline $\begin{array}{l}\text { 1. Ikan/ } \\
\text { Fish }\end{array}$ & 2.949 & $\begin{array}{c}5,6 \\
(8,8)\end{array}$ & 7.004 & $\begin{array}{c}6,4 \\
(9,1)\end{array}$ & 9.374 & $\begin{array}{c}6,1 \\
(9,2)\end{array}$ \\
\hline 2. Pangan/Food & 33.345 & 63,3 & 76.854 & 70,2 & 101.692 & 66,6 \\
\hline 3. Total/Total & 52.712 & 100,0 & 109.523 & 100,0 & 152.784 & 100,0 \\
\hline $\begin{array}{l}\text { Kota+Desa } \\
\text { Urban +Rural: }\end{array}$ & & & & & & \\
\hline $\begin{array}{l}\text { 1. Ikan/ } \\
\text { Fish }\end{array}$ & 3.348 & $\begin{array}{c}4,8 \\
(8,6)\end{array}$ & 7.67 & $\begin{array}{c}5,6 \\
(8,9)\end{array}$ & 10.675 & $\begin{array}{c}5,2 \\
(8,8)\end{array}$ \\
\hline 2. Pangan/Food & 38.725 & 55,3 & 86.511 & 62,9 & 120.649 & 58,5 \\
\hline 3. Total/Total & 70.062 & 100,0 & 137.453 & 100,0 & 206.336 & 100,0 \\
\hline
\end{tabular}

Sumber/Source: BPS, Susenas 1996,1999,2002 (Diolah/Processed)

*) Angka dalam kurung adalah total proporsi pengeluaran ikan terhadap pangan/Values in the parenthesis is the proportion of fish expenditive to food expenditure 
konsumsi masyarakat. Sejalan dengan temuan yang dilaporkan Fagi \& Simatupang (1998) bahwa krisis ekonomi yang terjadi bukanlah masalah ketersediaan tetapi lebih banyak ditentukan oleh terbatasnya daya beli masyarakat akibat krisis ekonomi.

Krisis ekonomi dan moneter mulai melanda Indonesia pada pertengahan tahun 1997 dan menyebabkan perubahan pada berbagai faktor, termasuk aktivitas sektor perikanan. Salah satunya adalah dampak pada harga berbagai komoditi. Tabel 2 menyajikan gambaran indeks harga jual komoditi perikanan untuk keperluan domestik maupun ekspor (Nikijuluw et al., 2000). Nyata terlihat bahwa harga kedua kelompok komoditi tersebut meningkat. Namun hingga akhir tahun 1998 terlihat bahwa harga barang ekspor meningkat secara meyakinkan, sementara harga barang domestik menurun pada tahun 1998 karena menurunnya daya beli masyarakat. Dengan asumsi bahwa harga penjualan secara proporsional pengeluaran konsumsi ikan cukup besar. Akan tetapi bila dibandingkan dengan pengeluaran rumah tangga lainnya, peningkatan tersebut sebenarnya masih relatif kecil. Proporsi pengeluaran konsumsi ikan sekitar $8,8 \%$ dari total pengeluaran konsumsi pangan (total). Bahkan jika dilihat dalam struktur pengeluaran rumah tangga keseluruhan (pangan dan bukan pangan) proporsi pengeluaran konsumsi ikan hanya sekitar $5,2 \%$ saja.

Apabila dibandingkan antara ketiga titik waktu dalam periode tersebut, terlihat bahwa proporsi pengeluaran konsumsi ikan, dari adanya peningkatan menjadi berkurang, yaitu dari 4,8\% pada tahun 1996 menjadi $5,6 \%$ pada tahun 1999 dan menjadi $5,2 \%$ pada tahun 2002. Selanjutnya bila dibandingkan antar wilayah ternyata meskipun secara nominal pengeluaran ikan terhadap total pengeluaran di perkotaan lebih besar dari pedesaan, tetapi dari proporsi pengeluaran antara kedua wilayah ternyata di pedesaan lebih besar (1,6\% pada setiap

Tabel 2. Indeks harga penjualan komoditi perikanan

Table 2. Price index of fish commodity

\begin{tabular}{ccc}
\hline \multirow{2}{*}{$\begin{array}{c}\text { Periodel } \\
\text { Period }\end{array}$} & $\begin{array}{c}\text { Indeks harga penjualanl } \\
\text { Wholeseller price indeks (1993=100) }\end{array}$ \\
\cline { 2 - 3 } & $\begin{array}{c}\text { Barang domestik/ } \\
\text { Domestic comodity }\end{array}$ & $\begin{array}{c}\text { Barang eksporl } \\
\text { Export comodity }\end{array}$ \\
\hline 1993 & 246 & 271 \\
1994 & 275 & 291 \\
1995 & 321 & 341 \\
1996 & 358 & 340 \\
1997 & 403 & 417 \\
1998 & 285 & 431 \\
Agustus 1997 & 410 & 401 \\
Agustus 1998 & 724 & 1.414 \\
Agustus 1999 & 365 & 337 \\
\hline Sumber/Source: & Dihitung dari buletin statistik bulanan, BPS, September 1999/ \\
\multicolumn{2}{c}{ Calculated from monthly statistic bulletin, CBS, September 1999 }
\end{tabular}

juga dinikmati oleh produsen barang-barang yang diekspor dibanding barang-barang yang diproduksi untuk domestik.

Seiring dengan kondisi tersebut, rata-rata pengeluaran konsumsi ikan dalam periode di atas meningkat tiga kali lipat (218,8\%), yaitu dari Rp 3.348,per kapita per bulan menjadi Rp 10.675,- per kapita per bulan. Sepintas terlihat bahwa peningkatan tahunnya). Informasi lainnya adalah proporsi pengeluaran ikan terhadap pangan baik di daerah perkotaan maupun daerah pedesaan tidak menunjukkan adanya perbedaan yang mencolok.

Kondisi ini akan lebih jelas bila didukung dengan informasi daya beli masyarakat yang ditunjukkan dari rata-rata pengeluaran untuk ikan per kapita sebulan menurut golongan pengeluarannya (Subiyakto, 2003). 
Termasuk informasi lain yang juga penting adalah pangsa pengeluaran pangan hewani selain ikan yaitu ternak (mencakup daging, telur dan susu) menurut kelompok pendapatan. Hal ini akan sangat bermanfaat terutama dalam perumusan kebijakan pembangunan pangan khususnya untuk memacu konsumsi pangan hewani. Pangsa pengeluaran pangan produk ternak dan ikan menurut kelompok pendapatan pada tahun 2002 dapat dilihat pada Tabel 3, yang menunjukkan bahwa pangsa pengeluaran pangan produk peternakan mengalami peningkatan secara konsisten sejalan dengan meningkatnya pendapatan. Demikian pula pangsa pengeluaran ikan walaupun dengan laju yang lebih rendah daripada pangan produk ternak.

Dari seluruh golongan pengeluaran, proporsi pengeluaran untuk konsumsi ikan berkisar dari $4 \%$ sampai $12 \%$ dari total pengeluaran. Dari gambaran tersebut, dapat disimpulkan bahwa konsumsi ikan dipengaruhi oleh besarnya pengeluaran rumah tangga atau oleh besarnya pendapatan yang diperoleh rumah tangga. Hal ini ditunjukkan dengan adanya informasi bahwa hampir seluruh rumah tangga pengeluaran belanja ikannya relatif sama proporsinya. Bahkan ada kecenderungan penurunan proporsi pengeluaran untuk ikan pada golongan pendapatan tinggi (> Rp 500.000) baik di desa maupun di kota.

Masyarakat berpendapatan rendah cenderung memberikan prioritas pada komoditas ikan dalam pemenuhan pangan hewani. Dengan semakin meningkat pendapatannya terjadi pergeseran preferensi dengan memberi prioritas yang lebih besar pada produk pangan ternak berupa daging, telur dan susu. Implikasinya adalah dalam memacu konsumsi ikan, indikator peningkatan pendapatan tidak cukup tetapi juga harus dilakukan perbaikan kualitas ikan melalui teknik pengolahan ikan (pengembangan produk) dan promosi/sosialisasi yang lebih intensif tentang peran ikan terhadap kesehatan dan kualitas hidup sumber daya manusia. Faktor distribusi, ketersediaan dan diversifikasi produk yang dapat dijangkau oleh masyarakat luas juga memegang peranan penting.

\section{Perkembangan Tingkat Konsumsi menurut Jenis Ikan}

Keadaan konsumsi ikan banyak dipengaruhi oleh ikan yang tersedia dimana ketersediaan ini banyak ditentukan oleh produksinya. Namun demikian, walaupun produksinya sudah cukup, keadaan ini belum menjamin konsumsinya juga cukup, karena adanya berbagai faktor yang berpengaruh. Produksi perikanan dalam periode 2000-2004 mengalami peningkatan rata-rata per tahun sebesar $5,23 \%$, yakni 5.107 juta ton pada tahun 2000 menjadi 6.231 juta ton pada tahun 2004, khususnya penangkapan di laut. Dalam periode yang sama, produksi perikanan tangkap

Tabel 3. Pangsa pengeluaran pangan produk ternak dan ikan menurut kelompok pendapatan, 2002

Table 3. Percentage of household expenditure compartment for meat and fish consumption by group expenditure

\begin{tabular}{cccccccc}
\hline $\begin{array}{c}\text { Ke lompok pendapatan } \\
\text { (Rp/kap/bulan)l } \\
\begin{array}{c}\text { Group expenditure } \\
\text { (Rp/cap/month) }\end{array}\end{array}$ & $\begin{array}{c}\text { Kota+Desal } \\
\text { Urban+Rural }\end{array}$ & \multicolumn{2}{c}{$\begin{array}{c}\text { Kotal } \\
\text { Urban }\end{array}$} & \multicolumn{2}{c}{$\begin{array}{c}\text { Desa/ } \\
\text { Rural }\end{array}$} \\
\cline { 2 - 8 } & $\begin{array}{c}\text { Ternak/ } \\
\text { Meat }\end{array}$ & $\begin{array}{c}\text { Ikan/ } \\
\text { Fish }\end{array}$ & $\begin{array}{c}\text { Ternak/ } \\
\text { Meat }\end{array}$ & $\begin{array}{c}\text { Ikan/ } \\
\text { Fish }\end{array}$ & $\begin{array}{c}\text { Ternak/ } \\
\text { Meat }\end{array}$ & $\begin{array}{c}\text { Ikan/ } \\
\text { Fish }\end{array}$ \\
\hline$<40.000$ & 1.2 & 11.6 & - & - & 1.2 & 11.6 \\
$40.000-59.999$ & 2.1 & 7.4 & 1.6 & 4.2 & 2.2 & 7.6 \\
$60.000-79.999$ & 3.4 & 7.6 & 4.4 & 5.4 & 3.2 & 7.9 \\
$80.000-99.999$ & 4.4 & 7.6 & 5.2 & 6.4 & 4.2 & 7.9 \\
$100.000-149.999$ & 6.3 & 8.6 & 7.8 & 8.0 & 5.7 & 8.8 \\
$150.000-199.999$ & 8.8 & 9.3 & 10.0 & 8.8 & 7.8 & 9.7 \\
$200.000-299.999$ & 11.7 & 9.3 & 12.8 & 9.0 & 10.0 & 9.9 \\
$300.000-499.999$ & 14.7 & 9.0 & 15.1 & 8.7 & 13.0 & 10.1 \\
$>500.000$ & 17.1 & 8.1 & 17.4 & 7.9 & 14.1 & 9.3 \\
\hline
\end{tabular}

Sumber/Source: SUSENAS, BPS (2002)

Keterangan/Remark: Nilai disajikan dalam persen/Values are in percentage 
Tabel 4. Perkembangan konsumsi beberapa jenis ikan menurut wilayah (Kg/kap/thn), 1996-2002

Table 4. Growth of various fish type consumption by region (Kg/cap/year), 1996-2002

\begin{tabular}{|c|c|c|c|c|c|c|c|c|c|}
\hline \multirow{2}{*}{$\begin{array}{l}\text { Jenis ikan/ } \\
\text { Fish type }\end{array}$} & \multicolumn{3}{|c|}{$\begin{array}{l}\text { Kotal } \\
\text { Urban }\end{array}$} & \multicolumn{3}{|c|}{$\begin{array}{l}\text { Desal } \\
\text { Rural }\end{array}$} & \multicolumn{3}{|c|}{$\begin{array}{l}\text { Kota+Desal } \\
\text { Urban+Rural }\end{array}$} \\
\hline & 1996 & 1999 & 2002 & 1996 & 1999 & 2002 & 1996 & 1999 & 2002 \\
\hline \multicolumn{10}{|l|}{$\begin{array}{l}\text { Ikan segar (Air payau dan } \\
\text { laut)/Fish fresh (brackish } \\
\text { water/marine): }\end{array}$} \\
\hline Ekor kuning/Yellow tail fish & 0.8 & 0.8 & 0.7 & 0.5 & 0.4 & 0.7 & 0.7 & 0.6 & 0.7 \\
\hline Tuna/Tunas & 4.7 & 3.5 & 2.4 & 3.2 & 2.6 & 2.4 & 3.8 & 3.0 & 2.4 \\
\hline $\begin{array}{l}\text { Tenggiri/Narrow bared king } \\
\text { mackerels }\end{array}$ & 0.5 & 0.3 & 0.3 & 0.3 & 0.2 & 0.2 & 0.4 & 0.2 & 0.3 \\
\hline Selar/Trevallies & 1.4 & 1.1 & 1.0 & 0.8 & 0.8 & 1.2 & 1.1 & 0.9 & 1.1 \\
\hline Kembung/Mackerels & 3.9 & 3.4 & 2.4 & 2.3 & 2.0 & 1.5 & 3.0 & 2.6 & 1.9 \\
\hline Teri/Anchovies & 0.9 & 0.8 & 0.6 & 1.2 & 0.7 & 0.7 & 1.1 & 0.8 & 0.7 \\
\hline Bandeng/Milkfish & 1.1 & 0.8 & 1.4 & 0.5 & 0.5 & 0.7 & 0.8 & 0.6 & 1.0 \\
\hline Gabus/Snakehead fish & 0.6 & 0.5 & 0.5 & 1.0 & 0.9 & 1.1 & 0.8 & 0.7 & 0.8 \\
\hline Kakap/Giant seaperch & 0.2 & 0.2 & 0.2 & 0.1 & 0.0 & 0.1 & 0.2 & 0.1 & 0.1 \\
\hline Baronang/Baronang & - & 0.1 & 0.1 & - & 0.1 & 0.1 & - & 0.1 & 0.1 \\
\hline Udang segar/Fresh shrimp & 0.9 & 0.8 & 0.8 & 0.4 & 0.3 & 0.4 & 0.6 & 0.5 & 0.6 \\
\hline Cumi-cumi/Common squids & 0.2 & 0.2 & 0.3 & 0.2 & 0.1 & 0.1 & 0.2 & 0.1 & 0.2 \\
\hline Kepiting/Common crabs & 0.1 & 0.1 & 0.1 & 0.0 & 0.0 & 0.1 & 0.1 & 0.1 & 0.1 \\
\hline \multicolumn{10}{|l|}{$\begin{array}{l}\text { Ikan segar (Air tawar)/Fish } \\
\text { fresh (freshwater): }\end{array}$} \\
\hline Mujair/Tilapias & 0.7 & 0.6 & 1.3 & 0.7 & 0.7 & 1.0 & 0.8 & 0.6 & 1.1 \\
\hline Mas/Common carp & 0.9 & 0.7 & 1.4 & 0.5 & 0.3 & 0.7 & 0.7 & 0.5 & 1.0 \\
\hline Lele/Catfish & 0.8 & 0.8 & 0.9 & 0.5 & 0.5 & 0.6 & 0.6 & 0.6 & 0.7 \\
\hline \multicolumn{10}{|l|}{ Ikan olahan/Fish processed: } \\
\hline Ikan kaleng/Canned fish & 1.3 & 0.1 & 0.1 & 1.6 & 0.1 & 0.1 & 1.5 & 0.1 & 0.1 \\
\hline $\begin{array}{l}\text { Udang olahan/Processed } \\
\text { shrimp }\end{array}$ & 0.3 & 0.1 & 0.1 & 0.1 & 0.1 & 0.1 & 0.2 & 0.1 & 0.1 \\
\hline $\begin{array}{l}\text { Ikan olahan lainnya/Other } \\
\text { processed fish }\end{array}$ & 9.1 & 2.8 & 1.6 & 14.1 & 3.5 & 2.5 & 11.6 & 3.1 & 2.1 \\
\hline Total/Total & 1.5 & 0.9 & 0.9 & 1.5 & 0.7 & 0.8 & 1.5 & 0.8 & 0.8 \\
\hline
\end{tabular}

Sumber/Source: SUSENAS, BPS (Diolah/(Proccesed)

secara keseluruhan meningkat sekitar $4,21 \%$ per tahun, yakni dari 4.112 juta ton pada tahun 2000 menjadi 4.837 juta ton pada tahun 2004 (Departemen Kelautan dan Perikanan (DKP), 2004).

Dari sisi konsumsi, berdasarkan data yang ditampilkan pada Tabel 4 dapat disimak keragaan konsumsi berbagai jenis ikan. Tingkat konsumsi ikan di daerah perkotaan lebih tinggi dari daerah pedesaan. Preferensi konsumsi ikan yang tinggi di kedua wilayah terutama pada jenis ikan: tuna, ikan olahan, dan kembung. Hal ini dapat dilihat dari relatif tingginya tingkat konsumsi ketiga jenis ikan tersebut dibanding 
Tabel 5. Perkembangan partisipasi konsumsi beberapa jenis ikan menurut wilayah (Kg/kap/thn), 1996-2002 Table 5. Growth of various fish type participation of fish consumption by region (Kg/cap/year), 1996-2002

\begin{tabular}{|c|c|c|c|c|c|c|c|c|c|}
\hline \multirow{2}{*}{$\begin{array}{l}\text { Jenis ikan/ } \\
\text { Fish type }\end{array}$} & \multicolumn{3}{|c|}{$\begin{array}{l}\text { Kotal } \\
\text { Urban }\end{array}$} & \multicolumn{3}{|c|}{$\begin{array}{l}\text { Desal } \\
\text { Rural }\end{array}$} & \multicolumn{3}{|c|}{$\begin{array}{l}\text { Kota+Desal } \\
\text { Urban+Rural }\end{array}$} \\
\hline & 1996 & 1999 & 2002 & 1996 & 1999 & 2002 & 1996 & 1999 & 2002 \\
\hline \multicolumn{10}{|l|}{$\begin{array}{l}\text { Ikan segar (Air payau dan } \\
\text { la ut)/Fish fresh (brackish } \\
\text { water/marine): }\end{array}$} \\
\hline Ekor kuning/Yellow tail fish & 7.3 & 8.1 & 9.9 & 4.2 & 4.6 & 6.8 & 5.4 & 6.3 & 8.4 \\
\hline Tuna/Tunas & 31.0 & 25.2 & 29.8 & 19.0 & 15.8 & 19.7 & 23.7 & 20.0 & 24.9 \\
\hline $\begin{array}{l}\text { Tenggiri/Narrow bared } k \text { ing } \\
\text { mackere/s }\end{array}$ & 6.2 & 3.9 & 3.6 & 3.0 & 2.3 & 2.3 & 4.1 & 2.9 & 3.0 \\
\hline Selar/Trevallies & 12.4 & 12.1 & 13.0 & 7.2 & 8.1 & 8.3 & 9.2 & 9.9 & 10.7 \\
\hline Kembung/Mackere/s & 29.1 & 26.9 & 25.7 & 14.1 & 14.9 & 13.2 & 19.5 & 20.4 & 19.6 \\
\hline Teri/Anchovies & 9.8 & 10.1 & 8.7 & 8.9 & 7.9 & 7.9 & 9.4 & 9.0 & 8.3 \\
\hline Bandeng/Milkfish & 9.1 & 7.5 & 9.4 & 4.2 & 4.0 & 5.1 & 6.7 & 6.0 & 7.3 \\
\hline Gabus/Snakehead fish & 7.6 & 7.5 & 8.0 & 10.3 & 10.2 & 11.3 & 9.2 & 9.1 & 9.6 \\
\hline Kakap/Giant seaperch & 2.3 & 2.2 & 1.8 & 1.1 & 0.7 & 1.1 & 1.7 & 1.4 & 1.4 \\
\hline Baronang/Baronang & - & 1.0 & 0.9 & - & 0.7 & 0.8 & - & 0.8 & 0.9 \\
\hline Udang segar/Fresh shrimp & 12.5 & 11.5 & 13.1 & 4.8 & 4.7 & 5.8 & 8.2 & 7.6 & 9.6 \\
\hline Cumi-Cumi/Common squids & 4.6 & 3.7 & 4.7 & 1.5 & 0.9 & 1.9 & 2.8 & 2.1 & 3.3 \\
\hline $\begin{array}{l}\text { Kepiting/Common crabs } \\
\text { Ikan segar (Air tawar)/Fish } \\
\text { fresh (freshwater): }\end{array}$ & 1.1 & 0.9 & 1.2 & 0.7 & 0.5 & 0.8 & 0.8 & 0.7 & 1.0 \\
\hline Mujair/Tilapias & 6.6 & 6.4 & 9.6 & 6.7 & 5.8 & 7.3 & 6.9 & 6.5 & 8.5 \\
\hline Mas/Common carp & 8.6 & 5.6 & 12.1 & 4.1 & 3.4 & 5.8 & 6.5 & 4.5 & 9.0 \\
\hline $\begin{array}{l}\text { Lele/Catfish } \\
\text { Ikan olahan/Fish } \\
\text { processed: }\end{array}$ & 2.9 & 3.1 & 5.9 & 2.9 & 3.3 & 5.2 & 3.0 & 3.4 & 5.6 \\
\hline Ikan kaleng/Canned fish & 2.3 & 1.1 & 2.7 & 2.7 & 1.3 & 2.3 & 2.6 & 1.3 & 2.5 \\
\hline $\begin{array}{l}\text { Udang olahan/Processed } \\
\text { shrimp }\end{array}$ & 2.5 & 1.6 & 2.5 & 2.1 & 1.5 & 1.8 & 2.3 & 1.6 & 2.2 \\
\hline $\begin{array}{l}\text { Ikan olahan lainnya/Other } \\
\text { processed fish }\end{array}$ & 49.3 & 47.9 & 40.0 & 58.2 & 56.8 & 47.6 & 56.0 & 55.1 & 43.8 \\
\hline Total/Total & 10.8 & 9.8 & 10.7 & 8.2 & 7.8 & 8.2 & 9.4 & 8.9 & 9.4 \\
\hline
\end{tabular}

Sumber/Source: SUSENAS, BPS (Diolah/(Proccesed)

jenis ikan lainnya dalam periode tahun 1996-2002. Pada tahun 2002 konsumsi ikan tuna, ikan olahan dan ikan kembung masing-masing sebesar: 2,4 $\mathrm{kg} ; 2,1 \mathrm{~kg}$ dan $1,9 \mathrm{~kg} / \mathrm{kapita} / \mathrm{tahun}$. Apabila dibandingkan dengan data pada tahun 1996, maka tingkat konsumsi tersebut cenderung menurun.

Besaran konsumsi ikan seperti di atas hanya dapat menunjukkan tingkat preferensi konsumsi 
rumah tangga tetapi belum menunjukkan arah perubahan (kecenderungan) preferensi yang mungkin berbeda antar wilayah. Padahal seiring dengan peningkatan pendapatan dan adanya faktor pengaruh non ekonomi lainnya, preferensi konsumsi ikan sangat mungkin berubah. Indikasi adanya perubahan preferensi dapat dilihat dari kecenderungan perkembangan tingkat konsumsi dan partisipasi rumah tangga yang mengkonsumsi ikan. Tingkat partsisipasi rumah tangga terhadap berbagai jenis ikan ditampilkan pada Tabel 5.

Arah perubahan preferensi konsumsi ikan di perkotaan yang dapat dikemukakan berdasarkan data pada Tabel 4 yang tampak bahwa preferensi konsumsi cenderung meningkat untuk jenis ikan: bandeng, mujair, mas dan lele. Tingkat konsumsi keempat jenis ikan tersebut pada tahun 2002 lebih besar dibanding pada tahun 1996 dan 1999. Peningkatan yang paling besar terlihat pada konsumsi ikan mujair yang mencapai lebih dari $100 \%$. Keadaan yang sebaliknya terjadi pada beberapa jenis ikan lainnya, dimana preferensinya cenderung menurun dalam periode tersebut. Hal ini terlihat dari lebih rendahnya tingkat konsumsi ikan-ikan tersebut pada tahun 1996 dibanding tahun 2002.

Di daerah pedesaan preferensi konsumsi yang meningkat adalah untuk jenis ikan: ekor kuning, selar, bandeng, gabus, kakap, mujair, mas, lele dan udang segar. Peningkatan paling besar untuk ikan ekor kuning, yaitu mencapai $75 \%$. Di wilayah ini konsumsi cumi-cumi, ikan kaleng dan udang olahan relatif tetap selama periode di atas, sedangkan konsumsi jenis ikan lainnya mengalami penurunan.

Berdasarkan data pada Tabel 4, penurunan yang sangat drastis adalah konsumsi ikan olahan dari tahun 1996 ke tahun 1999 dan 2002, baik di daerah perkotaan ataupun pedesaan. Penurunan yang terjadi pada kedua wilayah tersebut mencapai sekitar $82 \%$, di samping faktor selera, rendahnya preferensi konsumsi ikan olahan ini tidak terlepas dari kemudahan mendapatkan ikan segar, karena ketersediaan potensi sumber daya perikanan yang cukup besar dan relatif merata di seluruh pelosok tanah air. Selain itu tingkat konsumsi ikan olahan ini cenderung lebih tinggi di daerah pedesaan dibanding perkotaan. Hal ini menunjukkan bahwa meskipun daerah pedesaan merupakan daerah produksi perikanan, tetapi karena pendapatan penduduk cenderung lebih rendah maka hanya mampu membeli ikan olahan yang harganya lebih murah jika dibandingkan ikan segar.

Tidak semua masyarakat dapat mengkonsumsi pangan hewani, karena banyak faktor yang mempengaruhi tingkat partisipasi dan konsumsi pangan. Bukan saja faktor ekonomi (pendapatan) tetapi juga faktor harga, lingkungan dan sosial budaya. Bahkan beberapa kasus menunjukkan tidak ada rasionalisasi dalam pemilihan pangan, sehingga unsur selera atau gengsi lebih dominan dalam penentuan atau pemilihan jenis pangan atau jenis olahan pangan.

Meskipun ikan telah dikenal namun tampaknya belum semua masyarakat mengkonsumsi. Masih sekitar 20-30\% masyarakat yang tidak mengkonsumsi ikan segar dan sekitar 50\% masyarakat tidak mengkonsumsi ikan olahan seperti terlihat pada Tabel 5.

Berdasarkan fisiknya, ikan merupakan salah satu jenis pangan yang cepat memerlukan penanganan karena sifatnya yang cepat rusak. Diduga hal ini juga mempengaruhi preferensi konsumsi ikan. Dilihat dari tingkat partisipasi konsumsi ikan bervariasi antar jenis ikan dan wilayah. Diantara jenis ikan segar, terdapat tiga jenis ikan yang mempunyai tingkat partisipasi tertinggi pada tahun 1996 untuk di kota adalah ikan tuna $(31,0 \%)$, ikan kembung $(29,1 \%)$ dan ikan selar $(12,4 \%)$, sedangkan untuk di desa masing-masing ikan tuna $(19,1 \%)$, ikan kembung $(14,1 \%)$ dan ikan gabus $(10,3 \%)$. Sementara tingkat konsumsi ikan terendah pada tahun 1996 adalah ikan kakap sebesar 2,3\% di kota dan $1,2 \%$ di desa. Situasi ini sesuai dengan yang hasil kajian Ariani (2004) bahwa tingkat partisipasi konsumsi ikan segar tinggi pada propinsi yang merupakan sentra produksi ikan. Tingkat partisipasi konsumsi ikan segar di Jawa hanya setengahnya daripada luar Jawa karena wilayah Jawa bukan merupakan sentra produksi ikan terutama ikan laut. Oleh karena itu upaya peningkatan konsumsi ikan segar dapat dilakukan dengan memperpanjang jangkauan pemasaran melalui peningkatan teknologi penyimpanan ikan.

Selain itu penyebab rendahnya konsumsi ikan terutama ikan segar adalah karena terlalu panjangnya rantai tata niaga perikanan dan jauhnya jarak tempuh, sementara teknologi "menyegarkan" ikan masih terbatas, sehingga masyarakat yang jauh dari sentra produksi sulit mendapatkan ikan segar. Kalaupun bisa mendapatkan, harganya relatif mahal dengan kualitas tidak terjamin daripada produk ternak seperti daging ayam atau telur. Selain itu ketersediaannya belum merata di pasaran. Aspek pengolahannya pun lebih rumit dan memakan waktu lebih lama.

Pada tahun 1999 dimana pada saat itu terjadi krisis ekonomi, pola tingkat partisipasi konsumsi ikan segar sama dengan pada waktu sebelum krisis 
(1996), hanya volumenya yang lebih kecil. Hal ini berarti jumlah rumah tangga yang mengkonsumsi ikan pada waktu krisis ekonomi lebih sedikit dibandingkan dengan keadaan sebelum krisis. Dan penurunan tersebut berlaku pada semua jenis ikan, kecuali jenis ikan teri di kota dan ikan lele di desa yang menunjukkan kebalikannya. Berbeda halnya dengan tingkat partisipasi untuk jenis ikan mas di kota mengalami peningkatan yang signifikan yaitu $113,7 \%$. Kemudian hanya ikan selar, ikan bandeng dan ikan olahan di kota serta ikan olahan di desa yang mengalami penurunan. Selain itu ternyata tidak ada substitusi konsumsi antara jenis ikan segar dan ikan olahan, karena tingkat partisipasi konsumsi ikan olahan juga menurun pada waktu krisis. Menarik disimak bahwa tingkat partisipasi konsumsi ikan kaleng sangat kecil dibandingkan dengan ikan olahan yang hanya mendapatkan perlakuan pengeringan/pengasapan saja.

Seperti telah dibahas sebelumnya, hampir semua jenis ikan mengalami penurunan pada waktu krisis ekonomi dan penurunan cukup besar terjadi pada ikan kaleng $(51,1 \%)$, ikan tenggiri $(37,3 \%)$ dan ikan mas $(34,9 \%)$ untuk di kota serta ikan kaleng $(50,8 \%)$, ikan kakap $(40,0 \%)$ untuk di desa. Sejalan dengan pemulihan ekonomi (1999-2002), ternyata peningkatan tingkat partisipasi tidak terjadi pada semua jenis ikan. Peningkatan partisipasi konsumsi hanya terjadi pada ikan ekor kuning, ikan tuna, ikan bandeng, ikan gabus, ikan mujair dan ikan mas. Bahkan peningkatan partisipasi pada ikan mas mencapai $116,5 \%$ dan ikan mujair $48,1 \%$ lebih tinggi dibandingkan dengan jenis ikan yang lain.

Lebih tingginya konsumsi ikan di daerah perkotaan daripada pedesaan tidaklah mengherankan, karena tingkat pengeluaran rumah tangga di wilayah perkotaan lebih tinggi daripada di pedesaan. Salah satu penjelasan yang paling mungkin dari kondisi tersebut adalah bila tingkat pendapatan masyarakat perkotaan lebih tinggi sehingga mampu membeli komoditas ikan terutama ikan segar yang harganya relatif mahal. Selain itu jalur distribusi di perkotaan dapat saja lebih mudah mengingat jalur transportasi yang lebih baik. Dengan kata lain di pedesaan belum terjadi usaha yang mendekatkan produsen dengan konsumen.

Penyebab lain yang diduga mendominasi adalah adanya persepsi masyarakat yang masih salah bahwa ada anggapan terlalu banyak makan ikan akan menimbulkan penyakit cacingan, serta ada anggapan bahwa memang sudah makan dengan ikan tetapi ikan yang dimaksud adalah ikan tahu, ikan tempe dan sebagainya. Sebagaimana yang disampaikan oleh Martianto (2004), bahwa konsumsi aktual pangan hewani termasuk ikan masih jauh dari kecukupan yang dianjurkan. Pendapatan, harga (daya beli) dan pengetahuan/budaya adalah faktor yang determinan.

Jika dibandingkan dengan beberapa negara lain yang termasuk ke dalam negara penghasil ikan dunia, maka Indonesia adalah negara dengan konsumsi per kapita paling rendah, bahkan lebih rendah dibandingkan dengan Philipina. Sebagai contoh, misalnya pada tahun 1990 saja, konsumsi per kapita Philipina sudah mencapai $24 \mathrm{~kg} / \mathrm{kap} / \mathrm{tahun}$. Sementara, konsumsi per kapita Jepang mencapai $110 \mathrm{~kg} / \mathrm{kap} /$ tahun (Dahuri, 2002).

\section{Implikasi Kebijakan Peningkatan Konsumsi Ikan}

Untuk lebih meningkatkan konsumsi ikan, kampanye gemar makan ikan sebagai makanan yang menyehatkan, mencerdaskan dan menguatkan harus terus digelorakan dengan berbagai pendekatan dan media penyampaian.

Konsumsi ikan juga terkait erat dengan kondisi ekonomi masyarakat, mengingat bagi sebagian masyarakat Indonesia produk perikanan yang beredar di pasaran masih terasa mahal. Dengan demikian konsumsi ikan dalam negeri memiliki peluang lebih besar untuk meningkat jika tingkat pendapatan masyarakat membaik. Oleh karena itu agar tingkat konsumsi ikan di Indonesia meningkat perlu didukung dengan peningkatan pendapatan masyarakat (DKP, 2004) dan pengentasan kemiskinan terutama masyarakat nelayan.

Upaya yang sudah dilakukan pemerintah dalam hal ini Direktorat Jenderal Perikanan Tangkap diantaranya adalah membuat dan melaksanakan berbagai kegiatan dalam lingkup program penyuluhan mulai dari poster, leaflet, flipchart, radio, TV spot, reportase radio dan TV, pembuatan film $16 \mathrm{~mm}$, pembuatan fillet sinetron, penyelenggaraan pameran, demonstrasi, sarasehan, lomba menu makan ikan dan pemberian paket ikan.

Upaya lain yang bisa dilakukan adalah melakukan pendidikan gizi kepada ibu untuk menyediakan menu ikan dalam komposisi makan keluarganya. Sebagaimana diketahui bahwa ibulah yang menjadi tonggak dalam pengenalan berbagai jenis makanan dalam keluarga terutama anak. Oleh karena itu diharapkan pengenalan ikan sudah diterapkan sejak dini. Dengan disertai upaya ini diharapkan tingkat konsumsi ikan masyarakat meningkat. Upaya-upaya tersebut harus dilakukan secara simultan dengan upaya optimalisasi perikanan tangkap (laut dan perairan umum) dan perikanan budidaya untuk menjaga keseimbangan antara supply dan demand. 


\section{KESIMPULAN DAN SARAN}

Seiring dengan meningkatnya pengeluaran (sebagai proksi dari pendapatan) terjadi peningkatan dan perubahan preferensi konsumsi ikan di tingkat rumah tangga. Hal ini didukung fakta meningkatnya konsumsi beberapa jenis ikan selama tahun 1996. 2002. Makin meningkatnya volume dan nilai baik ekspor dan impor beberapa produk perikanan sehingga nilai perdagangan menurun juga menunjukkan bukti peningkatan (perubahan) preferensi konsumsi tersebut. Telah terjadi penurunan rata-rata tingkat konsumsi ikan baik di daerah perkotaan maupun pedesaan.

Ikan memegang peranan strategis dalam meningkatkan kualitas sumber daya manusia Indonesia. Permasalahannya adalah baik ikan segar maupun ikan olahan belum dikonsumsi oleh semua masyarakat, masih sekitar $20-30 \%$ dan $50 \%$ masyarakat yang tidak mengkonsumsi ikan segar dan ikan olahan. Oleh karena itu berbagai upaya masih diperlukan untuk mendorong peningkatan konsumsi ikan. Diantaranya adalah upaya peningkatan konsumsi ikan rumah tangga agar kecukupan konsumsi ikan yang direkomendasikan tercapai sehingga diperoleh SDM yang cerdas dan berkualitas seiring dengan upaya peningkatan pendapatan masyarakat, situasi harga yang kompetitif, stabil dan terjangkau.

\section{DAFTAR PUSTAKA}

Anonim. 2004b. Konsumsi Rakyat Terhadap Ikan Masih Rendah. http://www.kompas.com/kompascetak/ 0405/22/ekonomi/1037697.htm.

Ariani, M. 2004. Analisis Situasi Ketersediaan dan Konsumsi Pangan Hewani. Disampaikan pada Diskusi Dukungan Perikanan dan Peternakan Rakyat dalam Memantapkan Ketahanan Pangan. Pusat Pengembangan Ketersediaan Pangan, Badan Bimas Ketahanan Pangan, Departemen Pertanian RI. 27 September 2004. Jakarta.

Badan Pusat Statistik. 1996. Survei Sosial Ekonomi Nasional 1996. BPS, Jakarta.

Badan Pusat Statistik. 1999. Survei Sosial Ekonomi Nasional 1999. BFS, Jakarta.
Badan Pusat Statistik. 2002. Survei Sosial Ekonomi Nasional 2002. BPS, Jakarta.

Dahuri, R. 2002. Paradigma Baru Pembangunan Indonesia Berbasis Kelautan. Institut Pertanian Bogor. $233 \mathrm{pp}$.

Departemen Kelautan dan Perikanan. 2004. Refleksi Pembangunan Kelautan dan Perikanan Tahun 2004 dan Rencana Kegiatan Tahun 2005. Departemen Kelautan dan Perikanan Republik Indonesia. Jakarta.

Fagi, A.M. dan P. Simatupang. 1998. Economic Induced Food Crisis: Indonesian Experience.

Hardono, G.S. dan M. Ariani. 1994. Pangan Hasil Ternak dan Penyiapan Mutu Sumber Daya Manusia (Kajian Preferensi Konsumsi dan Alokasi Pengeluaran Rumah Tangga terhadap Pangan Hasil Ternak di Jawa Timur). Makalah disampaikan pada Pertemuan IImiah Hasil Penelitian Peternakan Lahan Kering. Malang, 26-27 Oktober 1994. Sub Balai Penelitian Ternak, Grati.

Martianto, D. 2004. Estimasi Kebutuhan Hewani untuk Memenuhi Kecukupan Gizi. Disampaikan pada Diskusi Dukungan Perikanan dan Peternakan Rakyat dalam Memantapkan Ketahanan Pangan. Pusat Pengembangan Ketersediaan Pangan, Badan Bimas Ketahanan Pangan, Departemen Pertaninan RI. 27 September 2004. Jakarta.

Nikijuluw, V.P.H. 1997. Analisis Permintaan dan Penawaran Ikan di Indonesia. Makalah disampaikan dalam Pra Widyakarya Nasional Pangan dan Gizi VI Sub Tema III. Jakarta, 4 Nopember.

Nikijuluw, V.P.H, A.K. Seta dan G.D.H. Jusuf. 2000. Reorientasi kebijakan pembangunan pasca krisis ekonomi. Prosiding Widyakarya Pangan dan Gizi VII. LIPI. Jakarta.

Nikijuluw, V.P.H dan Abdurrahman. 2004. Analisis potensi kelautan dalam mendukung pemantapan ketahanan pangan. Widyakarya Pangan dan Gizi VIII. LIPI. Jakarta.

Subiyakto. 2004. Peningkatan Kemandirian Ikan dalam Suryana, A. Kemandirian Pangan Menuju Ketahanan Pangan Berkelanjutan. Kerjasama Badan Bimas Ketahanan Pangan, Departemen Pertanian dengan Harian Umum Suara Pembaruan. Jakarta.

Suhardjo. 1997. Peninjauan Kembali Pola Pangan Harapan dan Penetapan Target Skor PPH. Makalah disampaikan dalam Pra Widyakarya Nasional Pangan dan Gizi VI Sub Tema III. Jakarta, 4 Nopember. 